\title{
Analisis Pelemahan Multipel pada Data 2D Seismik Laut "IS" dengan Metode Transformasi Radon
}

\author{
Indah Permatasari' ${ }^{1}$, Oki Hedriana ${ }^{2}$
}

${ }^{1}$ Institut Teknologi Telkom Purwokerto, Purwokerto, 53147, Indonesia

${ }^{2}$ Lembaga Minyak dan Gas Bumi, Jakarta Selatan, 12230, Indonesia

\section{Info Artikel}

\section{Histori Artikel:}

Diterima: 11 Maret, 2020

Direvisi: 10 Agustus, 2020

Diterbitkan: 1 September, 2020

\section{Kata kunci:}

multipel

seismik

water bottom

tranformasi radon

\section{Keywords:}

multipel

seismic

water bottom

radon tranformation

Penulis Korespondensi:

Indah Permatasari

indah@ittelkom-pwt.ac.id

\section{ABSTRAK}

Multipel termasuk noise pada data seismik laut yang mengganggu dalam interpretasi sehingga perlu untuk diminimalisir keberadaannya. Multipel dapat menimbulkan ambiguitas pada data seismik laut sehingga tidak dapat menggambarkan kondisi bawah permukaan yang sebenarnya. Salah satu metode yang digunakan untuk penelitian ini adalah metode transformasi radon yang bertujuan untuk melemahkan multipel. Pada penelitian ini diperoleh data seismik laut "IS" terdapat water bottom multiple pada time $600-1400 \mathrm{~ms}$ dengan waktu tempuh dua kali lipat dari waktu seabed. Hasil yang diperoleh setelah diterapkan metode transformasi radon menunjukkan multipel dapat terlemahkan dengan baik sehingga penampang seismik dapat menggambarkan kondisi bawah permukaan yang sebenarnya.

\begin{abstract}
Multipel is noise in marine seismic data which is disturbing in interpretation so it needs to be minimized. Multiple can cause ambiguity in marine seismic data and therefore can not describe the actual subsurface conditions. One of the methods used for this study is a radon transformation that aims to weaken multiple. In this research, "IS" marine seismic sata is obtained with water bottom multiple at $600-1400 \mathrm{~ms}$ with twice the seabed time. The result obtained after applying the radon transformation method show multiple can be weakened properly so that the seismic section can describe the true subsurface conditions.
\end{abstract}

\section{PENDAHULUAN}

Pengolahan data seismik merupakan tahapan yang penting untuk memperoleh penampang seismik yang mewakili kondisi bawah permukaan. Gelombang seismik yang terekam tidak seutuhnya berupa data primer, akan tetapi terdapat data pengganggu yang disebut dengan noise. Noise tersebut tergolong sebagai pengotor data sehingga harus diminimalisir keberadaannya. Multipel salah satu jenis koheren noise yang menjadi permasalahan serius pada data seismik laut karena akan menimbulkan ambiguitas pada data. Hal ini terjadi karena gelombang yang menjalar ke bawah permukaan terekam lebih dari satu kali waktu yang diperlukan untuk merambat akibat kontras impedansi yang besar. Perbandingan sinyal refleksi dan noise yang terekam akan mempengaruhi kualitas dari data seismik tersebut. Oleh karena itu, diperlukan suatu metode agar multipel dapat terlemahkan sehingga mendapatkan kualitas section seismik yang baik.

Beberapa metode yang dikenal dalam pelemahan multipel diantaranya metode filter $\mathrm{f}-\mathrm{k}$ dan transformasi radon. Kedua metode tersebut dikembangkan untuk meminimalisirkan noise khususnya 
multipel. Transformasi radon dapat diaplikasikan pada data seismik dengan kedalaman laut dangkal maupun dalam. Metode transformasi radon yang diterapkan pada data sintetik dan data real mampu mengatenuasi noise dengan optimal sehingga menghasilkan signal to noise rasio yang tinggi tanpa menganggu data primernya (Meng, Li, dkk., 2016). Pengindentifasikan multipel dilakukan untuk memisahkan multipel dengan data primernya. Proses pelemahan multipel menggunakan transformasi radon tergantung pada resolusi multipel dan data primer pada domain radon (Xue, dkk., 2016). Efektifitas metode transformasi radon untuk menghilangkan multipel dengan optimal berdasarkan penentuan parameter radon dan pemilihan kecepatan NMO yang tepat untuk koreksi NMO pada $C M P$ gather (Ogagarue dan Ebeniro, 2014).

Penerapan transformasi radon pada data seismik laut "IS" diharapkan dapat melemahkan multipel sehingga menghindari kesalahan dalam menginterpretasi serta menghasilkan perbaikan pada penampang seismik. Oleh karena itu, pada penelitian ini bertujuan untuk menganalisis pelemahan multipel pada data seismik laut dengan metode transformasi radon. Hasil yang diperoleh dari pengolahan data seismik ini akan dianalisa efek dari pelemahan multipel tersebut terhadap kandungan data primernya.

\section{METODE}

Tahapan-tahapan yang digunakan pada penelitian ini terdiri atas preprocessing data seismik, analisa kecepatan, koreksi NMO, tansformasi radon dan migrasi. Pengolahan data seismik laut "IS" menggunakan software Promax dengan data tipe SEG-Y.

\subsection{Preprocessing Data Seismik}

Tahapan ini meliputi input geometri yang bertujuan untuk mengkorelasikan parameter lapangan terhadap informasi observer report. Selanjutnya melakukan filtering dengan menggunakan bandpass filter. Filtering tersebut untuk menghilangkan frekuensi yang mengganggu data seismik. Frekuensi rendah dipilih sebesar $5-9 \mathrm{~Hz}$ dan frekuensi tinggi sebesar $70-80 \mathrm{~Hz}$ sehingga penampang seismik menjadi lebih bersih. Proses bandpass filter tersebut khususnya digunakan untuk meredam gelombang seismik yang terkontaminasi noise frekuensi rendah dan frekuensi tinggi seperti ambient noise.

Tahapan berikutnya mengembalikan energi yang hilang akibat atenuasi gelombang dengan TAR (True Amplitude Recovery). TAR bertujuan untuk mengkompensasi energi dimana amplitudo gelombang seismik yang seharusnya didapatkan melalui parameter test dengan menyesuaikan amplitudo data (Wulandari, dkk., 2015). Dekonvolusi merupakan proses terakhir dari processing data dengan menggunakan proses autokorelasi untuk mempertajam wavelet. Autokorelasi ini dengan memilih wavelet yang lebih spike sehingga memiliki resolusi yang tinggi. Pada saat proses dekonvolusi prediktif, tahapan yang penting adalah menentukan nilai operator length dan prediction distance dengan nilai gap yang dipilih harus melebihi nilai interval dari data sampel (Chintia, dkk., 2017).

Berikut ini merupakan penentuan nilai operator length dan operator prediction distance seperti gambar dibawah ini: 


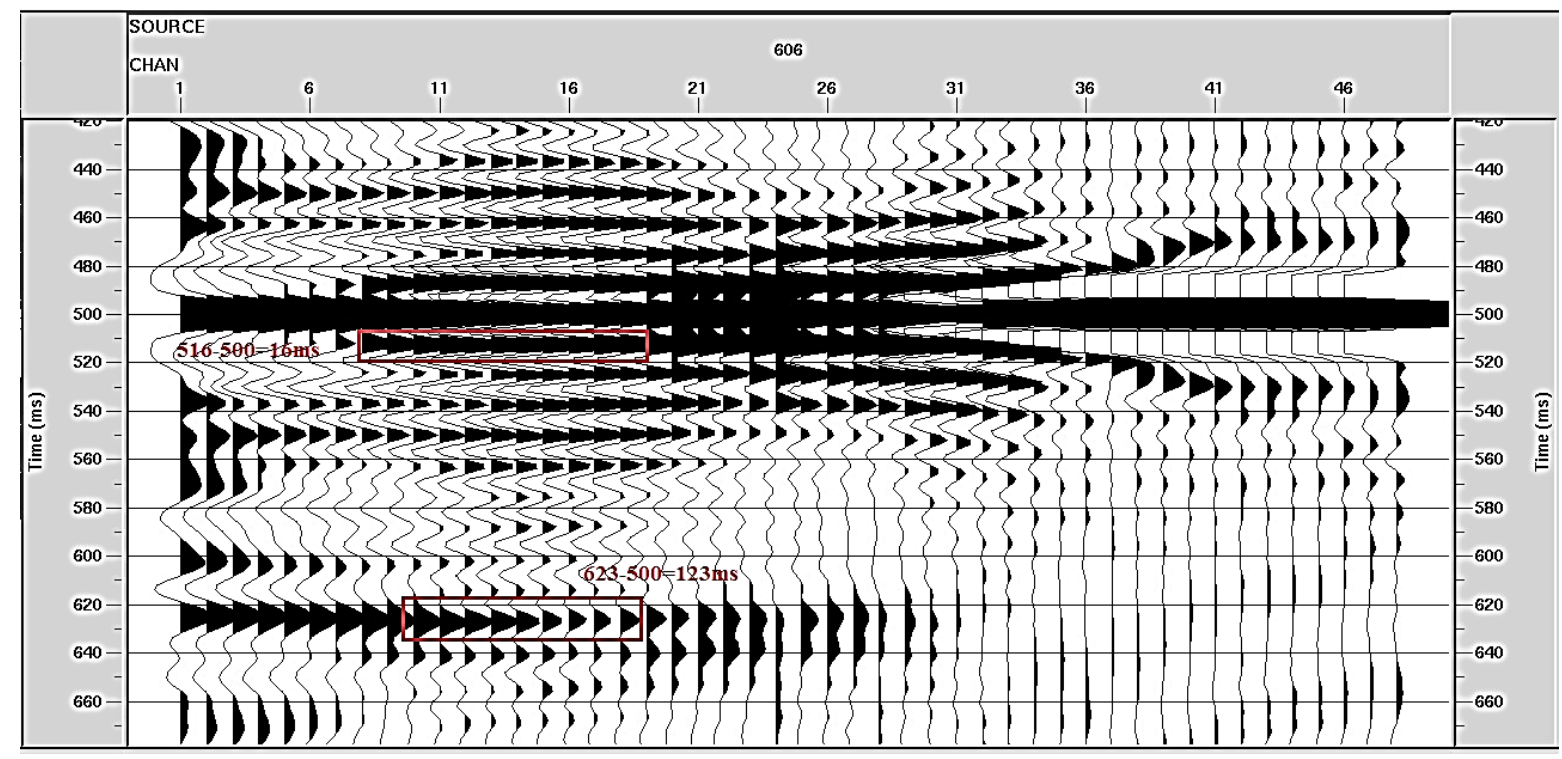

Gambar 1. Proses Autokorelasi untuk Menentukan Nilai Operator Prediction Distance dan Second Zero Crossing

Data gather pada gambar 1. menunjukkan kekonsistenan wavelet data seismik dapat dilihat melalui proses autokorelasi. Penentuan parameter autokorelasi ini menghasilkan nilai operator prediction distance sebesar $123 \mathrm{~ms}$ diambil dari zona transient autokorelasi karena zona ini merepresentasikan zona yang tidak dipengaruhi multipel. Nilai operator prediction distance didapatkan dari time hasil autokorelasi pada saat second zero crossing sebesar $16 \mathrm{~ms}$.

\subsection{Transformasi Radon}

Metode transformasi radon pada prinsipnya mentransformasi data dari domain $(\mathrm{t}-\mathrm{x})$ menjadi domain $(\tau-p)$ agar sinyal primer dan multipel dapat terpisahkan. Hal ini bertujuan agar sinyal-sinyal refleksi dalam kumpulan data yang tertumpuk, dapat dibedakan berdasarkan perbedaan moveout. Dimana pada proses ini pemilihan kecepatan harus dilakukan dengan tepat untuk mengkoreksi moveout dari sinyal primer dan multipel. Dengan demikian multipel mudah teramati setelah diaplikasikan koreksi NMO. Pada transformasi radon akan memetakan data sebelum dan sesudah koreksi NMO sehingga dapat diidentifikasi dalam domain radon (Cao, dkk., 2003). Prinsip kerja dari transformasi radon yaitu mentransformasikan data dari domain waktu-jarak $(t-x)$ ke dalam domain intercept time - ray parameter $(\tau-p)$ yang disebut sebagai parameter sinar. Hukum Snellius berlaku untuk menggambarkan penjalaran suatu berkas sinar pada medium berlapis yaitu:

$$
\frac{\sin \theta_{1}}{v_{1}}=\frac{\sin \theta_{2}}{v_{2}}=\ldots=\frac{\sin \theta_{n}}{v_{n}}=\text { konstant } a=p
$$

Hubungan penjalaran berkas sinar yang melewati suatu medium dengan waktu tempuh penjalaran sinar, maka diperoleh rumusan matematis nilai parameter sinar sebagai berikut:

$$
\Delta t=\frac{\sin \theta \cdot \Delta t}{v}=p \cdot \Delta x
$$

Berdasarkan persamaan (2) nilai parameter sinar dipengaruhi oleh besarnya sudut datang sinar dengan kecepatan sinar tersebut dalam merambat sebuah medium. Parameter sinar untuk transformasi radon pada data seismik, secara matematis ditunjukkan melalui persamaan:

$$
\tau=t-p \cdot \Delta x
$$

Dimana $\tau$ adalah domain zero-offset time, $t$ adalah waktu penjalaran sinar dan $\mathrm{p}$ adalah parameter sinar. 
Berikut ini event seismik refleksi dengan menggunakan pada transformasi radon slant-stack.

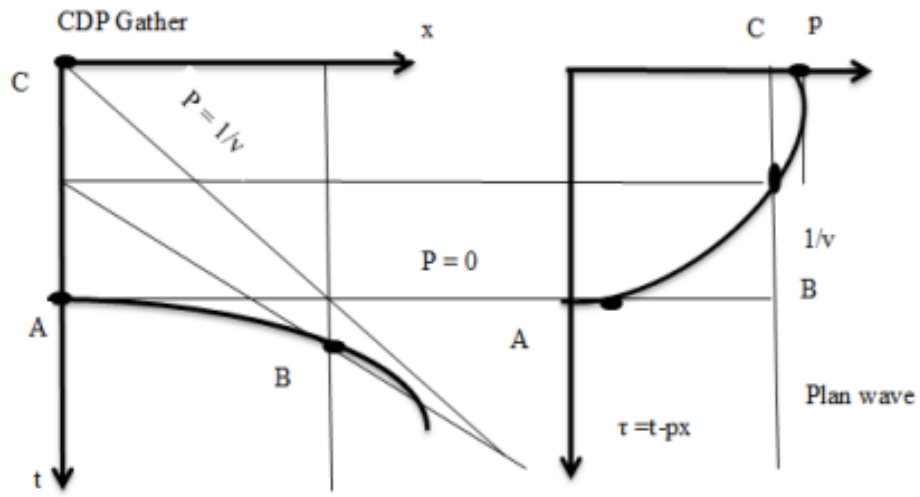

Gambar 2. Transformasi Radon (Yilmaz, 2001)

Pada gambar 2 menunjukkan sebuah event hiperbolik seperti sebuah sinyal atau multipel yang berada di domain $(t-x)$. Untuk memisahkan sinyal primer dengan multipel maka data ditransformasikan ke domain $(\tau-p)$ membentuk elips sehingga energi dari sinyal-sinyal refleksi yang tertumpuk akan terpisah, karena energi diatur oleh moveout.

\subsection{Diagram Alir Penelitian}

Tahapan-tahapan penelitian yang dilakukan untuk pelemahan multipel menggunakan tranformasi radon digambarkan pada diagram alir penelitian dibawah ini:

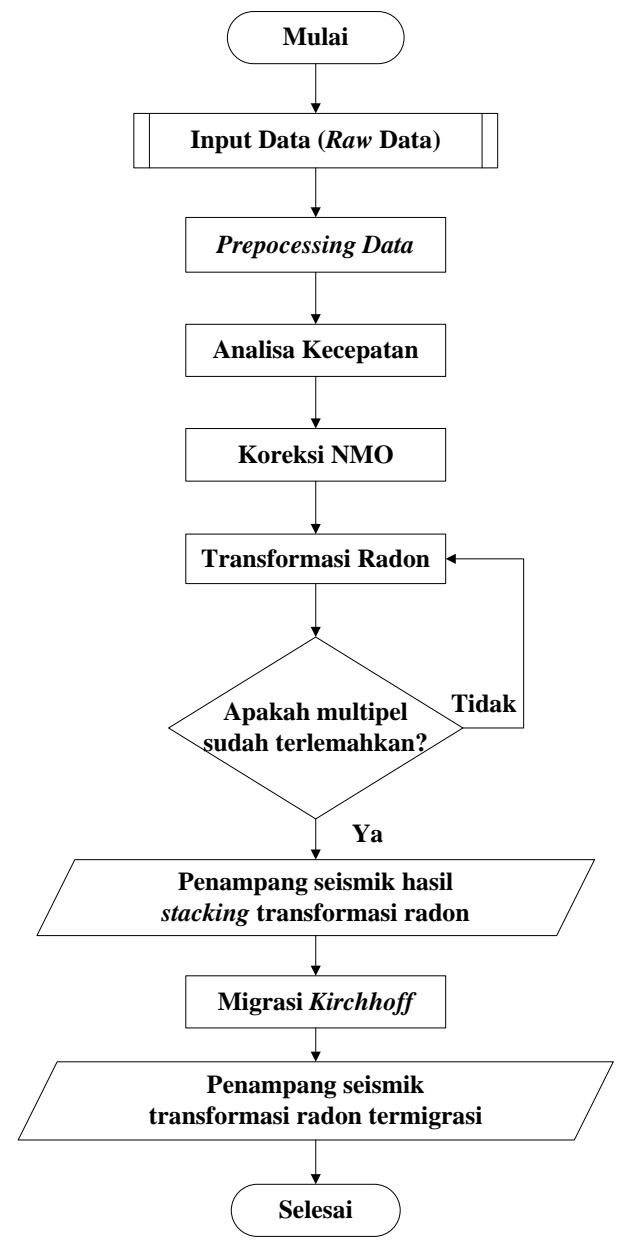

Gambar 3. Diagram Alir Penelitian Pelemahan Multipel menggunakan Tranformasi Radon 


\section{HASIL DAN DISKUSI}

Kecepatan pada data diperoleh melalui picking semblance, parameter yang digunakan untuk membangun semblance yaitu CDP fold sebesar 16 fold, CDP increment yang digabungkan setiap 50 CDP dan nilai minimum kecepatan semblance $1500 \mathrm{~m} / \mathrm{s}$ dan kecepatan maksimum $4000 \mathrm{~m} / \mathrm{s}$. Metode semblance dalam melakukan picking kecepatan mengacu pada pola kemenerusan refleksi gelombangnya. Berikut ini hasil dari penampang stacking kecepatan .

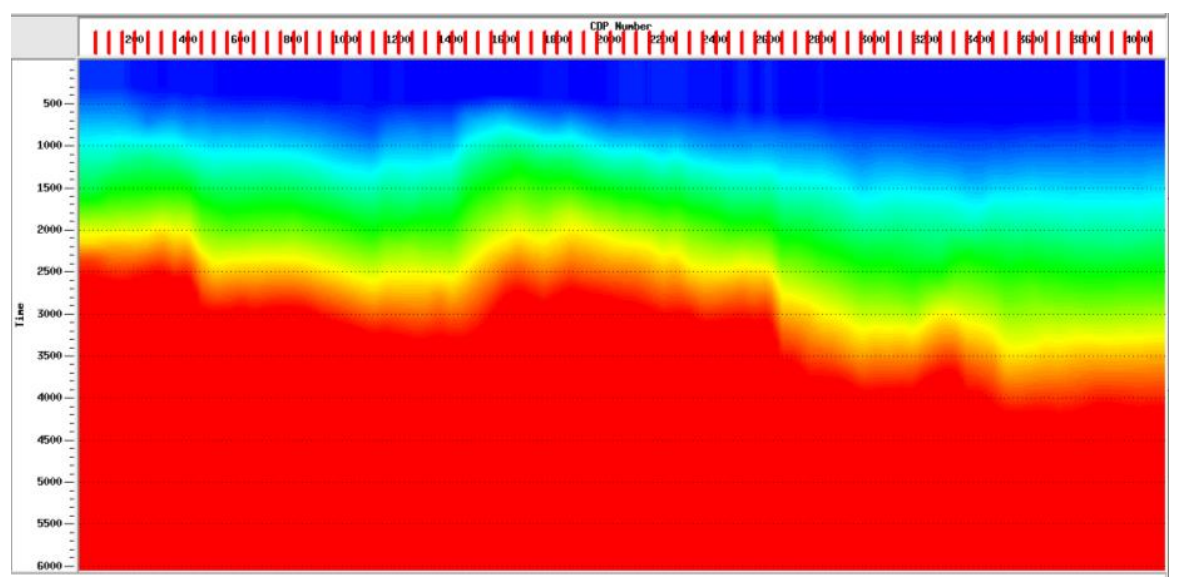

Gambar 4. Hasil Penampang Stacking Kecepatan

Hasil penampang stacking kecepatan pada gambar 4 menunjukkan kontur warna dengan nilai kecepatan pada interval time tertentu. Daerah pada warna merah menunjukkan kecepatan yang lebih tinggi dari warna biru maupun hijau. penampang stacking kecepatan menunjukkan hasil yang baik dimana terlihat kontur warna membentuk pola dari penampang data seismiknya. Stacking data seismik akan menghasilkan sinyal refleksi dengan kualitas yang baik jika pemilihan kecepatan dilakukan dengan tepat untuk inputan pada proses normal moveout correction (Elzawam, 2019).

Hasil trace seismik pada data seismik "IS" sebelum terkoreksi NMO akan menggambarkan event multipel dan event primer sebagai event hiperbola. Akan tetapi, setelah diterapkan koreksi NMO multipel menempati posisi yang tetap yakni melengkung ke bawah. Sedangkan event primer akan terangkat keatas membentuk event horisantal yang lurus. Berikut display gather sebelum dan setelah dilakukan koreksi NMO.

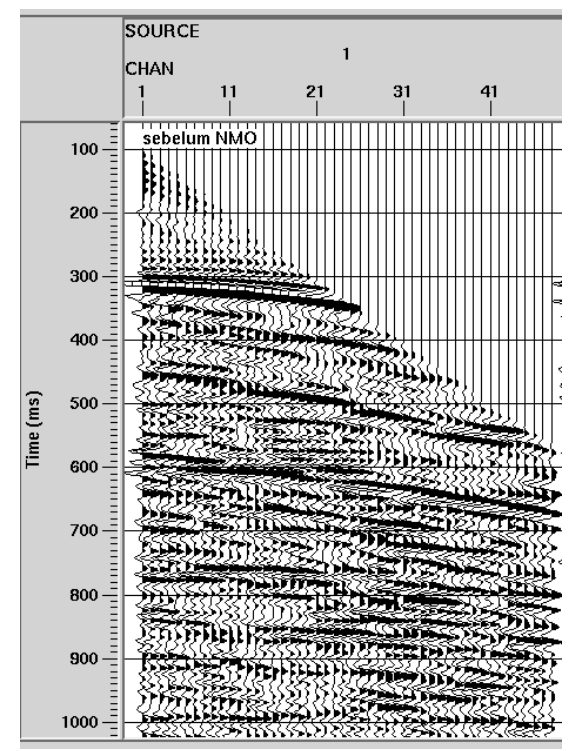

(a)

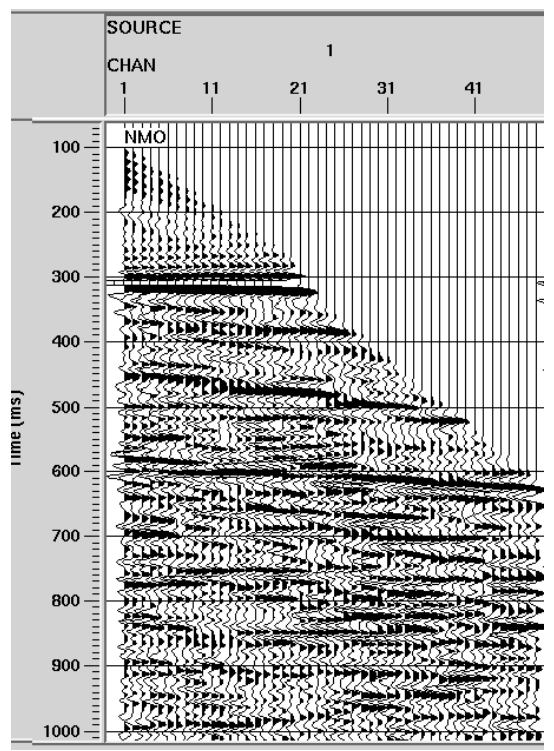

(b)

Gambar 5. (a) Sebelum koreksi NMO dan (b) Sesudah Data Terkoreksi NMO 
Koreksi NMO dapat menghilangkan efek jarak sehingga trace seismik berubah menjadi zero offset yang ditujukkan pada gambar 5 event primer pada nomer 1 setelah koreksi NMO berubah menjadi horisontal pada time $310 \mathrm{~ms}$. Sedangkan multipel ditujukkan nomer 2 pada dimana event multipel tetap berbentuk hiperbola karena multipel memiliki kecepatan yang lebih rendah dari pada event primer.

Pelemahan multipel akan dilakukan dengan metode transformasi radon dengan data masukan berupa data gather yang sudah terkoreksi NMO. Interpolasi dilakukan setelah dilakukan koreksi NMO sehingga dapat mereduksi noise multipel secara lateral (Deng, dkk., 2016). Secara umum metode transformasi radon digunakan untuk melemahkan multipel dengan meloloskan sinyal primer berdasarkan residual moveout dari offset terdekat sampai offset terjauh. Parameter yang mempengaruhi pada transformasi radon tersebut antara lain maksimum moveout, frekuensi maksimum dan $\mathrm{p}$ trace. Nilai maksimum moveout pada data ini sebesar $200 \mathrm{~ms}$ karena ditinjau dari nilai kemiringan moveout yang dapat terbentuk. Besar frekuensi data yang dominan sebesar $70 \mathrm{~Hz}$ dan besarnya nilai parameter sinar p trace sebanyak 36 yang menggambarkan suatu berkas sinar melewati medium berlapis. Selanjutnya data pada domain $(\mathrm{t}-\mathrm{x})$ di transformasikan ke dalam domain $(\tau-p)$. Pada domain $(\tau-p)$ dilakukan pembuatan desain muting untuk melemahkan multipel tanpa mengganggu sinyal primernya.

Berikut desain muting yang dilakukan berdasarkan perbedaan moveout-nya:

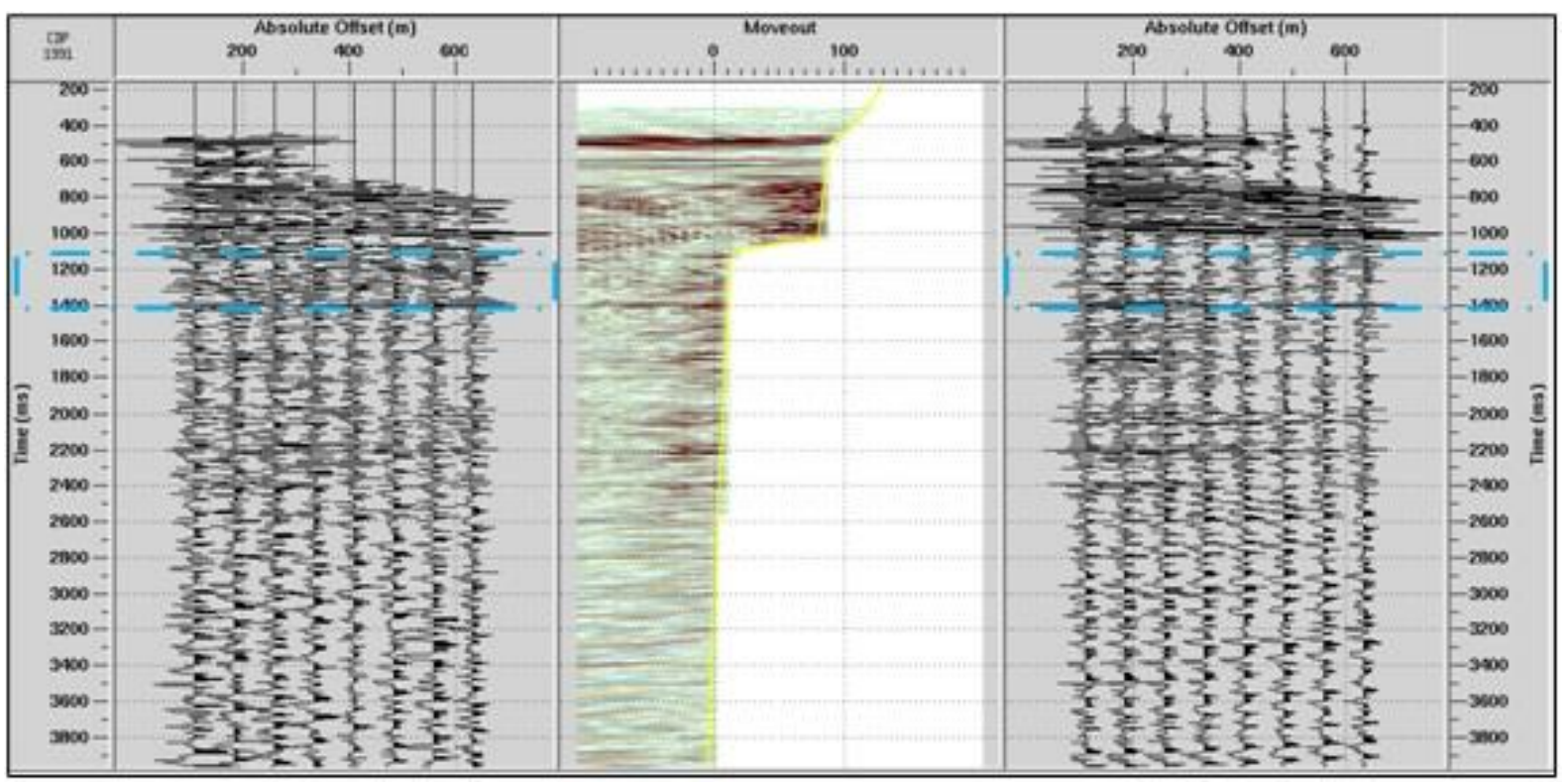

Gambar 6. Desain Muting menggunakan Transformasi Radon

Pemisahan multipel dan sinyal primer dilakukan dengan melakukan muting seperti pada gambar 6 kotak warna merah yang menunjukkan zona multipel terindikasi pada time $1200 \mathrm{~ms}$. Proses muting pada domain (tau-p) dilakukan secara halus (smooth) agar sinyal primer tetap terjaga (Arifudin, dkk., 2015). Pada gambar terlihat bahwa setelah dilakukan muting terjadi pelemahan amplitudo sehingga dapat dikatakan multipel tereduksi dengan baik. Berikut ini hasil penampang seismik "IS" sebelum dan setelah diterapkan metode transformasi radon. 


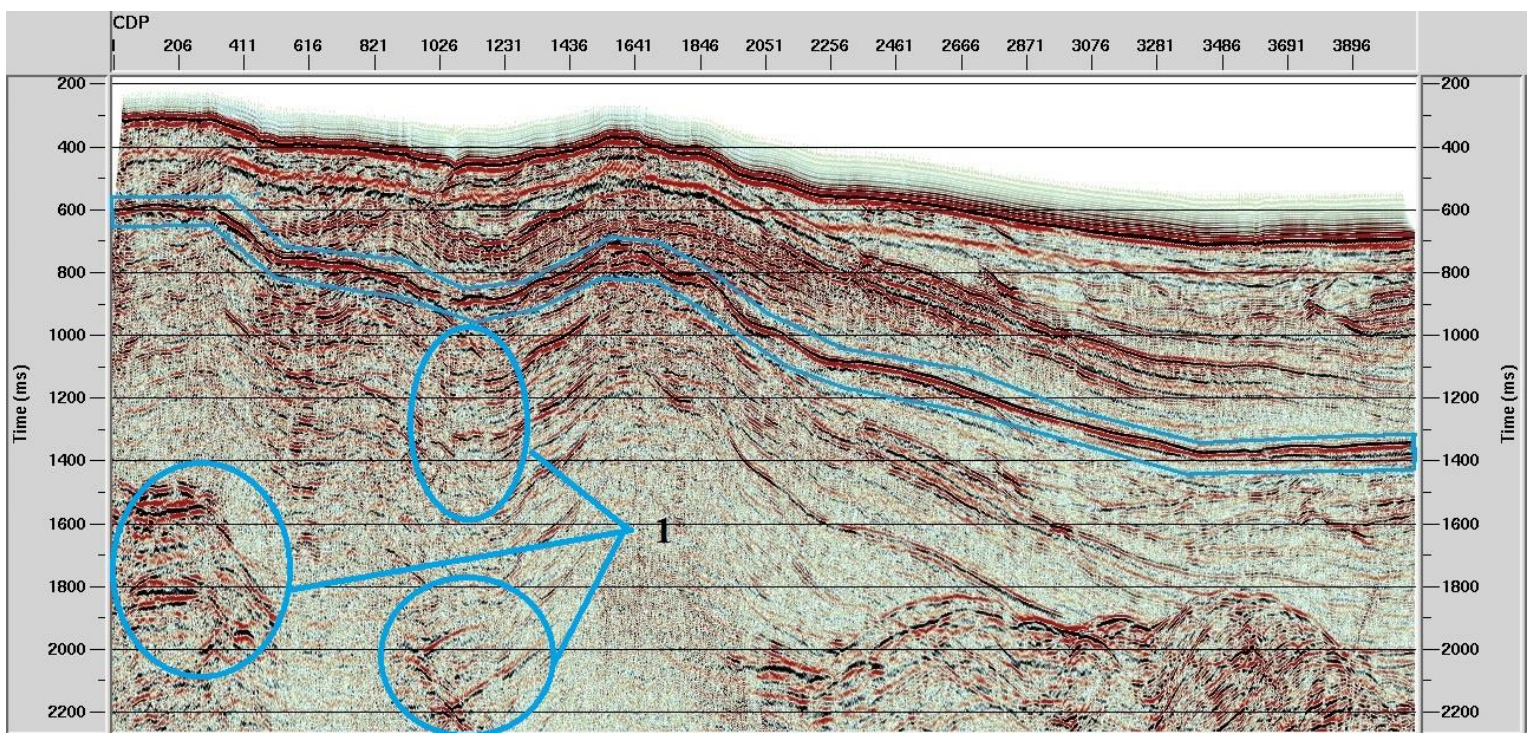

(a)

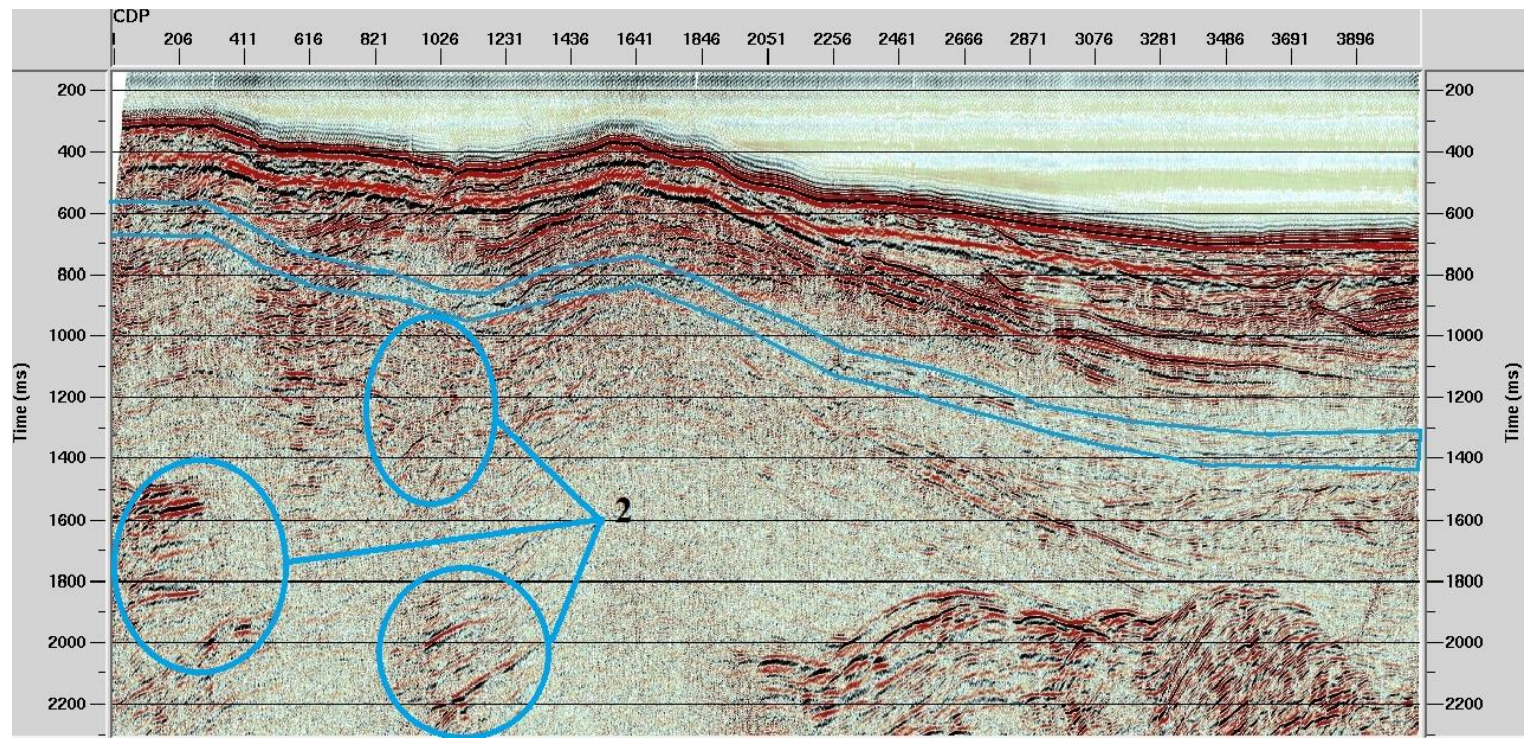

(b)

Gambar 7. Hasil Penampang Seismik (a) Sebelum Transformasi Radon dan (b) Setelah Transformasi Radon

Pembahasan gambar 7.a merupakan analisis dari keberadaan multipel pada data penampang stacking hasil pengolahan data. Keberadaan multipel sangat jelas terlihat pada sepanjang garis warna biru. Multipel tersebut termasuk kedalam jenis water bottom multiple pada time $600 \mathrm{~ms}$ sampai 1400 ms. Multipel muncul karena hasil perulangan refleksi dari reflektor yang disebut dengan seabed yang berada pada time $300 \mathrm{~ms}$ sampai $700 \mathrm{~ms}$. Kehadiran reflektor semu akibat dari interferensi water bottom multiple terhadap reflektor primernya mengakibatkan penampang seismik menjadi tidak tepat (Subarsyah dan Nainggolan, 2014). Multipel pada data ini memiliki bentuk morfologi yang sama dengan seabed. Posisi dari multipel tersebut berada pada dua kali time dari sinyal primer atau reflektor yaitu pada time $300-700 \mathrm{~ms}$.

Penampang pada gambar 7.b menunjukkan data yang telah diterapkan transformasi radon terlihat multipel pada time 600-1400 ms multipel terlemahkan terlihat pada zona yang berwarna biru. Hasil penampang seismik sangat baik setelah menerapkan metode transformasi radon dimana data bersih dari multipel. Akan tetapi, terdapat beberapa sinyal-sinyal primer yang ikut terlemahkan terlihat perbedaan pada zona nomer 1 dan 2 . Hal ini karena metode radon kurang mampu membedakan sinyal primer dan multipel pada data yang memiliki jarak offset pendek karena ketika ditransformasikan ke 
dalam domain radon sinyal primer dan multipel akan terlihat sama. Keberhasilan pelemahan multiple berpengaruh terhadap panjangnya offset, dimana transformasi radon sangat berhasil diterapkan pada far offset (Yuza, dkk., 2020). Berikut ini merupakan perbedaan sebelum dan setelah multipel terlemahkan pada CDP 1846 - 4031.

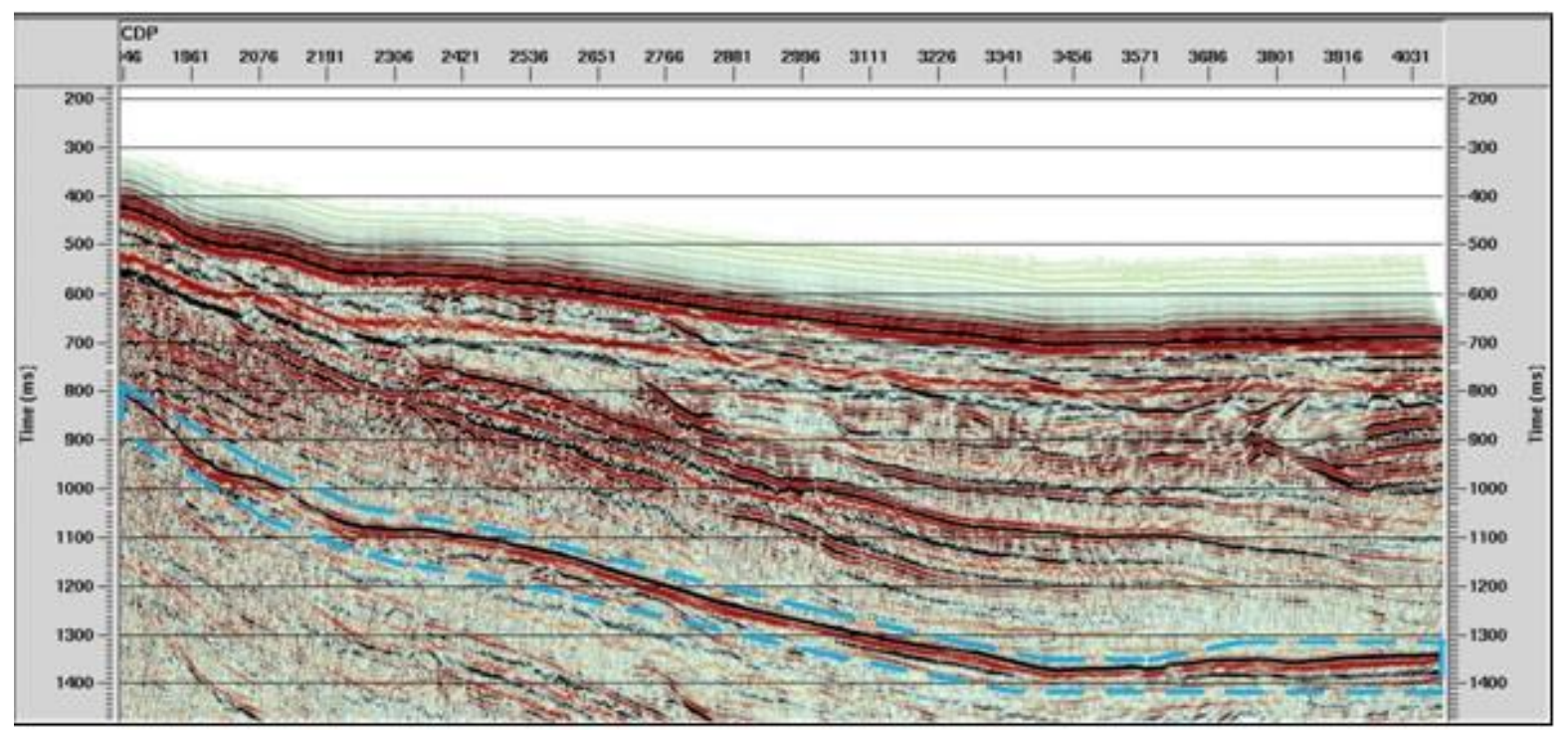

(a)

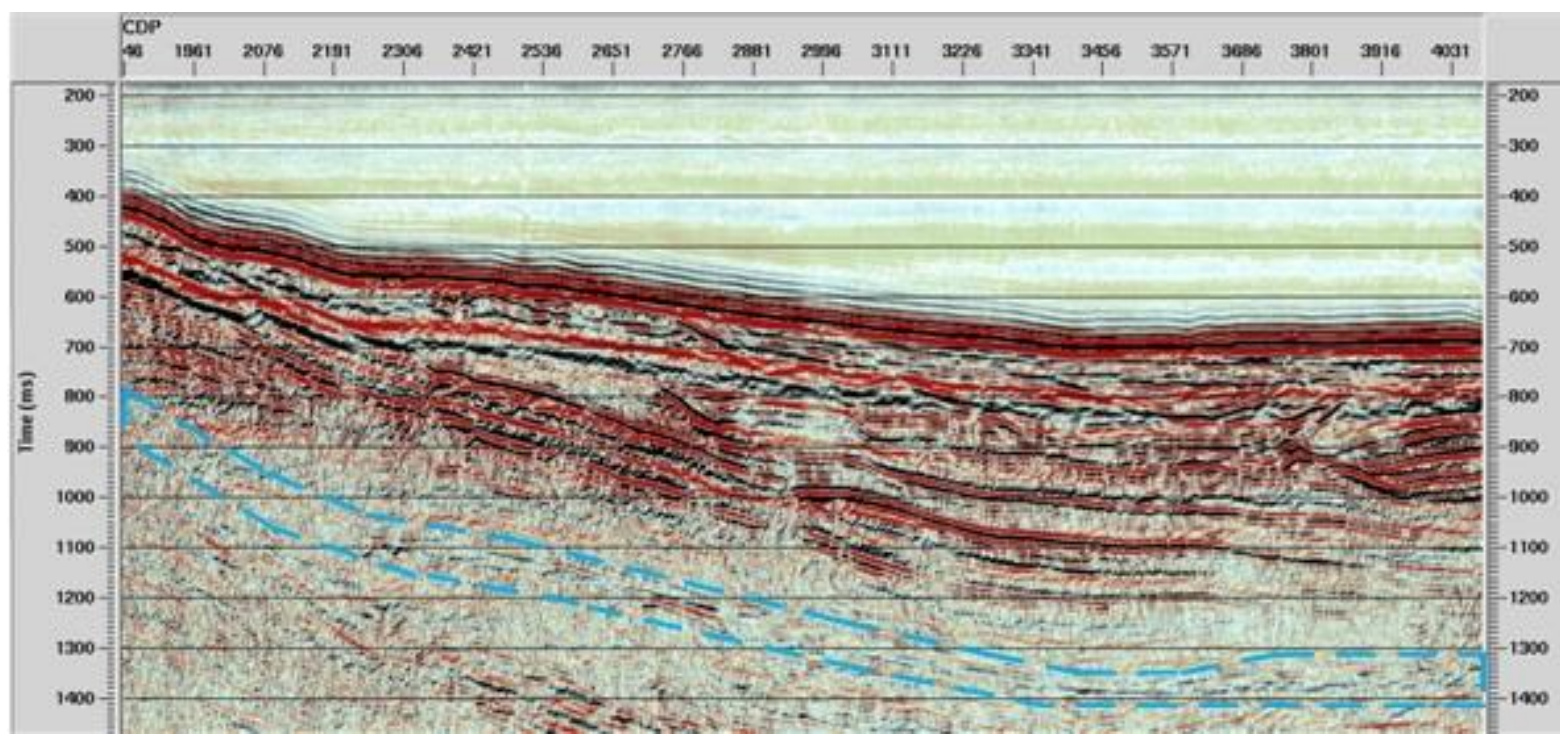

(b)

Gambar 8. Perbedaan (a)Sebelum Multipel Terlemahkan (b) Pelemahan Multipel Menggunakan Metode Tranformasi Radon

Penampang seismik pada gambar 8.a merepresentasikan zona multipel pada range CDP 1846 4031. Pelemahan multipel dengan metode transformasi radon yang diterapkan pada data seismik "IS" sangat optimal terlihat pada Gambar 8.b. Pelemahan multipel tersebut dapat menggambarkan kondisi bawah permukaan yang sebenarnya.

Migrasi adalah salah satu tahapan untuk mereduksi gelombang seismik yang terdifraksi sehingga struktur penampang seismik terlihat jelas (Yenti, dkk., 2015). Efek difraksi pada data seismik disini yaitu kehadiran efek bowtie. Penerapan migrasi kirchhoff pada penampang data seismik yang telah bersih dari multipel merupakan tahapan akhir dalam processing data seismik ini. Keunggulan dari 
migrasi kirchhoff dapat menghasilkan pencitraan reflektor yang lebih kontinyu (Susanti, dkk., 2020). Berikut ini perbedaan penampang seismik sebelum dan setelah dilakukan migrasi kirchhoff.

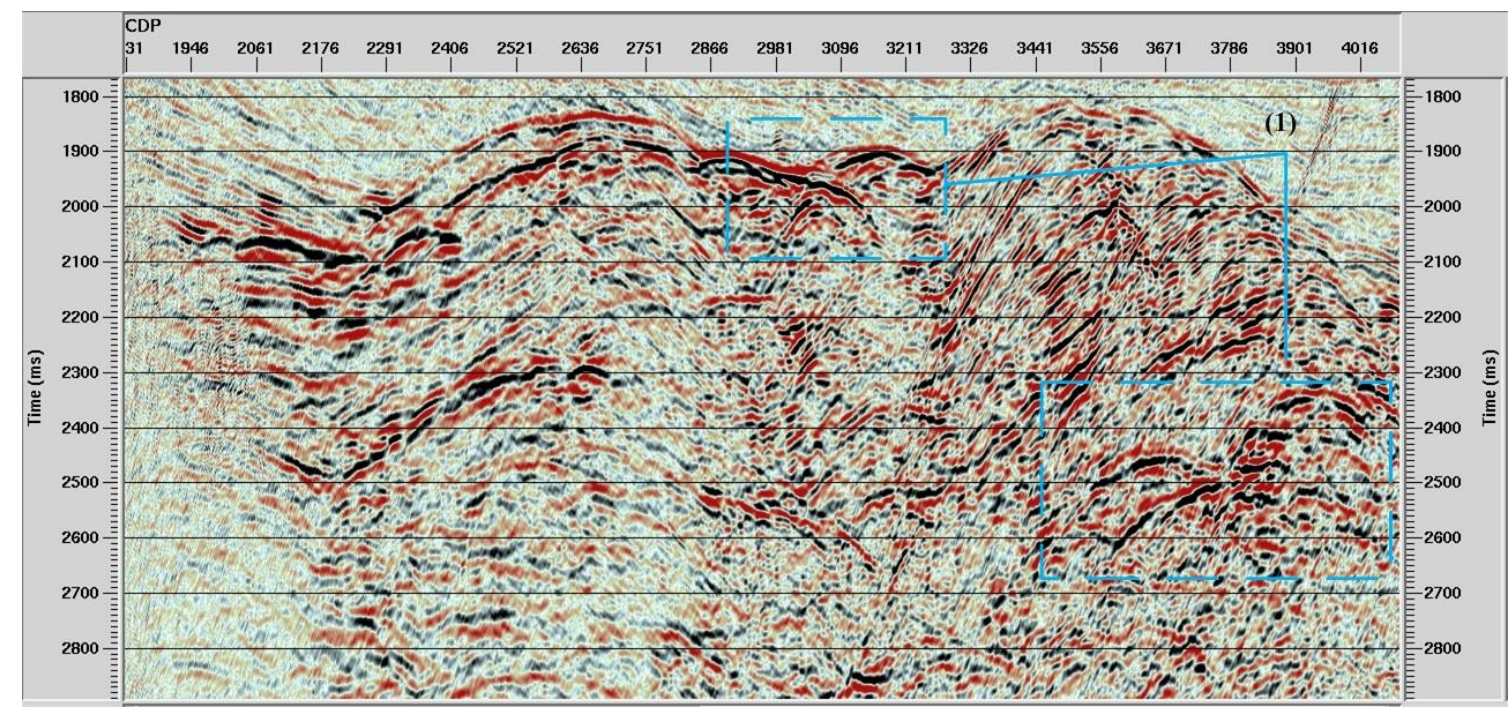

(a)

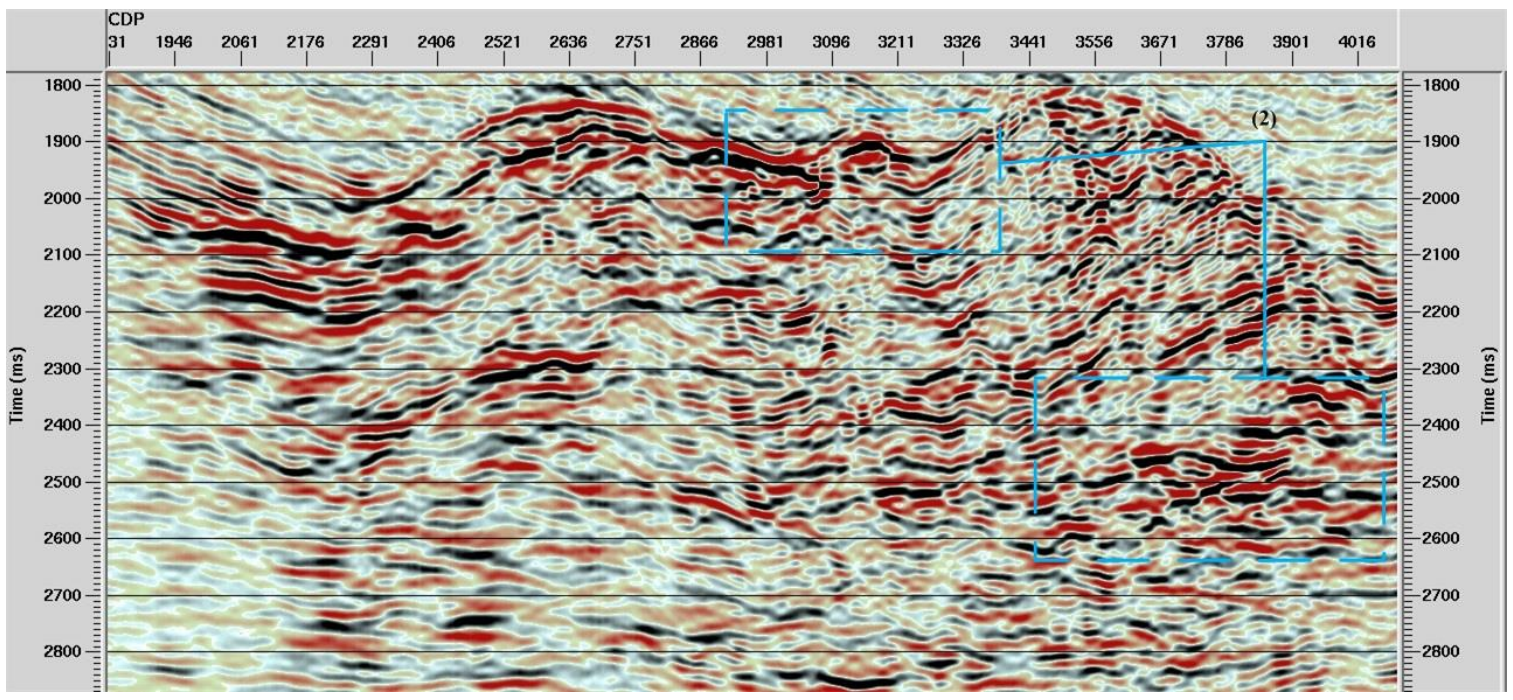

(b)

Gambar 9. Penampang Seismik (a) Sebelum Migrasi (b) Setelah Migrasi

Pada penampang seismik yang belum dilakukan migrasi masih terdapat difraksi. Difraksi ini terlihat dari kenampakan efek bowtie yang terlihat jelas pada gambar 9.a yang ditunjukkan pada kotak warna biru. Efek bowtie ini terlihat reflektor yang mengkungan ke bawah. Pada dasarnya proses migrasi kirchhoff ini memindahkan posisi reflektor dengan menjumlahkan titik amplutido dari reflektor dengan mengestimasi posisi sebenarnya (Wiratama, dkk., 2019). Pada gambar 9.b menunjukkan setelah dimigrasi reflektor kembali ke posisi sebenarnya berdasarkan reflektifitas lapisan bumi.. Reflektifitas suatu bidang refleksi yang semula tidak menyambung maupun selaras satu sama lain dan dipenuhi oleh efek difraksi bowtie pada nomer 1, setelah dimigrasi pada nomer 2 reflektor menjadi lebih jelas dan teratur. 


\section{KESIMPULAN}

Penerapan metode transformasi radon pada data seismik "IS" dapat melemahkan water bottom multiple dengan baik pada time 600 sampai $1400 \mathrm{~ms}$ namun terdapat beberapa sinyal primer yang ikut terlemahkan. Penampang seismik yang dihasilkan bersih dari multipel sehingga dapat mewakili kondisi bawah permukaan yang sebenarnya.

\section{DAFTAR PUSTAKA}

Arifudin, Sota, I., \& Siregar, S. S. (2015). Supresi Multipel pada Data Seismik Laut dengan Metode Dekonvolusi Prediktif dan Radon Demultipel. Jurnal Fisika FLUX, 12 (2), 100-108.

Cao, Z., Bancroft, J. C., Brown, R. J., \& Chunyan. (2003). Radon Transform and Multiple Attenuation. Crewes Research Report, 15, 1-22.

Chintia, B., Ivansyah, O., \& Sampurno, J. (2017). Analalisis Parameter Gap dalam Tahapan Dekonvolusi Prediktif Guna Mereduksi Short Period Multipke dan Meningkatkan S/N Ratio pada Pengolahan Data Seismik Refleksi 2D Marine. Positron, VII (1), 25-33.

Deng, S., Zhao, W., \& Liu, Z. (2016). Surface-based Internal Multiple Elimination in the CMP Domain - Theory and Application Strategies on Land Seismic Data. Acta Geophysica, 64 (6), 2114-2135.

Elzawam, N. M. (2019). Applied NMO Correction to Seismic Data (Dynamic Correction) Consider 2D Model Case. Journal of Pure and Applied Sciences , 18 (2), 141-147.

Meng, F., Li, Y., Liu, Y., Tian, Y., \& Wu, N. (2016). Application of the Radon-FCL Approach to Seismic Random Noise Suppression and Signal Preservation. Journal of Geophysics and Engineering , 13, 549558.

Ogagarue, D., \& Ebeniro, J. (2014). Water Bottom Multiple Elimination and Data Quality Enhancement Using Parabolic Radon Transform: A Case Study of 3D Seismic Data from Offshore Niger Delta. Journal of Geosciences and Geomatics , 2 (4), 172-177.

Subarsyah, \& Nainggolan, T. B. (2014). Atenuasi Water-Bottom Multiple dengan Metode Transformasi Parabolic Radon. Jurnal Geologi Kelautan, 12 (3), 145-152.

Susanti, W., Ivansyah, O., Muliadi, \& Avianthara, B. (2020). Analisis Perbandingan Migrasi Metode Kirchhoff dan Migrasi Fx pada Data Seismik 2D Darat. Prisma Fisika, 8 (1), 21-25.

Wiratama, R., Purwanto, C., \& Denya, R. (2019). Application of Pre-Stack Time Migration (PSTM) Using Kirchoff Method on Marine Seismic Data 2D in Sulawesi Sea Water. IOP Conference Series: Journal of Physics 1175(2019)012015 .

Wulandari, I., Manik, H. M., \& Subarsyah. (2015). Penerapan Metode Common Reflection Surface Pada Data Seismik Laut 2D di Laut Flores. Jurnal Teknologi Perikanan dan Kelautan , 6 (2), 209-217.

Yaru, X., Jing, Y., Ma, J., \& Chen, Y. (2016). Amplitude-Preserving Nonlinear Adaptive Multiple Attenuation Using The High-Order Sparse Radon Transform. Journal of Geophysics and Engineering , 13, 207-219.

Yenti, V. L., \& Namigo, E. L. (2015). Pre-Stack Time Migration (PSTM) Berbasis Seismic Unix Pada Data Seismic 2D Cekungan Bryant Canyon Lepas Pantai Teluk Louisiana Texas. Jurnal Fisika Unand , 4 (1), 36-42.

Yilmaz, O. (2001). Seismic Data Processing. Tulsa: Society of Exploration Geophysicists.

Yuza, N. H., Nainggolan, T. B., \& Manik, H. M. (2020). Multiple Attenuation Methods in Short-Offset 2D Marine Seismic Data: A Case Study in Cendrawasih Bay. IOP Conference Series: Earth and Environmental Science 429012031 Retievered from https://iopscience.iop.org/article/10.1088/17551315/429/1/012031/meta. 